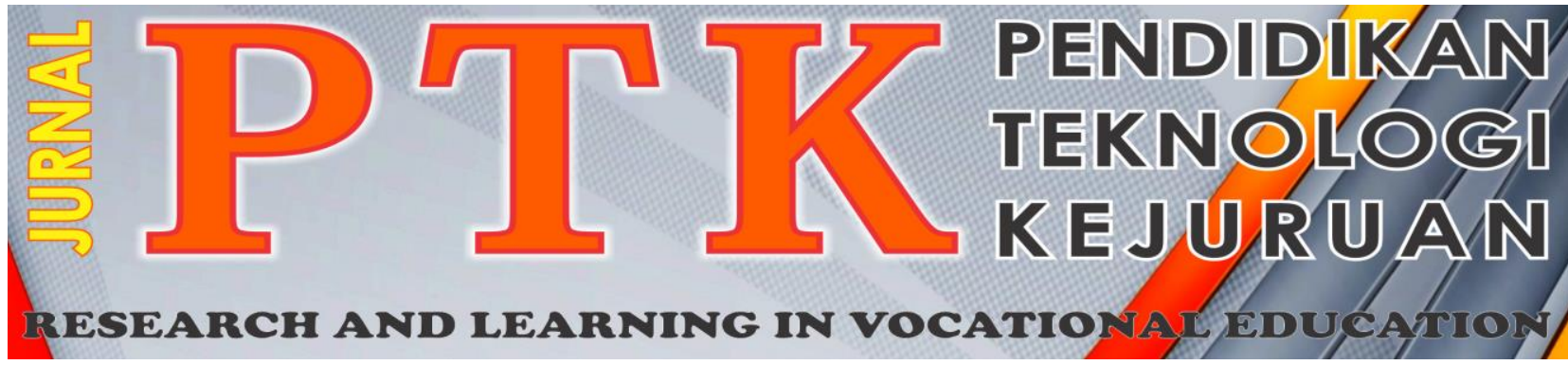

Vol. 2, No. 4, 2019

P-ISSN: 2621-3273

E-ISSN: 2621-1548

\title{
Review Implementasi Teknologi Informasi dan Komunikasi dalam Kegiatan Pembelajaran: Studi Kasus SMK di Kota Padang Panjang
}

\author{
Remon Lapisa ${ }^{1,2 *}$ Irma Y.B ${ }^{2}$, Milana ${ }^{2}$ dan Ahmad Arif ${ }^{2}$ \\ ${ }^{1}$ Jurusan Teknik Mesin, Fakultas Teknik, Universitas Negeri Padang \\ ${ }^{2}$ Jurusan Teknik Otomotif, Fakultas Teknik, Universitas Negeri Padang \\ "Corresponding author, e-mail: remonlapisa@ft.unp.ac.id
}

\begin{abstract}
Abstrak - Penerapan Teknologi Informasi dan Komunikasi (TIK) pada kegiatan belajar mengajar memberikan pengaruh besar dalam peningkatan kualitas pendidikan terutama di era revolusi industri 4.0 seperti sekarang ini. Penelitian ini bertujuan untuk mengetahui sejauh mana tingkat kesiap-terapan TIK dalam kegiatan pembelajaran pada guru SMK. Penelitian eksperimen ini menggunakan pendekatan survei dengan menyebarkan angket kepada responden dengan bidang keahlian mata pelajaran yang berbeda. Hasil penelitian menunjukan bahwa penggunaan TIK sebagai alat bantu kegiatan belajar mengajar belum terlaksana secara optimal. Hal ini disebabkan oleh rendahnya kemampuan guru dalam penguasaan teknologi informasi dan koumnikasi. Disamping itu, tidak tersedianya infrastruktur TIK yang memadai di sekolah menyebabkan pengembangan model pembelajaran berbasis TIK berjalan tidak seperti yang diharapkan. Perbaikan menyeluruh perlu dilaksanakan agar pengembangan model pembelajaran berbasis TIK dapat terlaksana dengan baik. Hasil penelitian ini diharapkan bisa memberikan feedback yang positif dalam rangka meningkatkan kualitas pendidikan secara umum.
\end{abstract}

\section{Kata kunci: Teknologi informasi dan komunikasi, kegiatan pembelajaran, kompetensi guru, media pembelajaran}

\begin{abstract}
The implementation of Information and Communication Technology (ICT) into learning activities presents a significant effect on the quality of education, especially in the era of the industrial revolution 4.0. The present study aims to evaluate the level of implementation of ICT in learning activities for vocational teachers. This experimental research used survey method by distributing questionnaires to respondents with different subject expertise.The results showed that the use of ICTs in learning process has not been implemented optimally. This is caused by the low competence of teachers in the sector of information and communication technology. In addition, the lack of ICT infrastructure in schools causes a deceleration in the development of ICT-based learning models. Comprehensive improvement need to be implemented so that the development of ICT-based learnings model can be performed. The results of this study are expected to provide positive feedback to improve the quality of Indonesian education
\end{abstract}

keywords: Information and communication technology, learning activities, teacher competencies, learning media

\section{Pendahuluan}

Teknologi informasi dan komunikasi (TIK) memegang peranan yang sangat penting dalam pengembangan dunia pendidikan. Pemanfaatan TIK secara optimal pada kegiatan pembelajaran memberikan berkontribusi positif pada peningkatan kualitas pendidikan. TIK berperan dalam kemudahan proses alih ilmu pengetahuan dan memperluas wawasan. Meski sebaliknya, TIK berpotensi dapat menimbulkan beberapa dampak negatif bagi peserta didik jika penggunaanya tidak dikontrol secara baik [1]. Pengontrolan yang ketat perlu dilakukan terutama bagi para generasi milenial yang sejak dini sudah terbiasa dengan berbagai peralatan media dan informasi [2].

Pada dunia pendidikan, TIK berperan dalam mempermudah proses komunikasi, akses informasi dan rekayasa/ pengolahan data. Hingga saat ini, pengembangan TIK mengalami peningkatan yang pesat dalam berbagai aspek antara lain [3]; (a) teknologi perangkat keras seperti komputer, harddisk dll, (b) teknologi aplikasi perangkat lunak seperti program simulasi dan administrasi perkantoran (MS Word, MS Excel, dll) dan (c) 
kapasitas jaringan seperti internet, wifi, LAN untuk memenuhi kebutuhan pengguna.

Untuk memastikan kualitas pengajaran, tenaga pengajar (dosen dan guru) dituntut untuk dapat beradaptasi secara baik dan mampu berinovasi dengan kemajuan TIK. Untuk menciptakan suasana kegiatan belajar mengajar (KBM) yang kondusif, maka guru harus bisa mempersiapkan media pembelajaran yang menarik dan informatif dengan menggunakan berbagai aplikasi yang tersedia. Dengan memanfaatkan TIK dan dilengkapi oleh kemudahan akses internet, maka kegiatan belajar dapat dilakukan kapan saja dan dimana saja dengan ruang lingkup yang lebih luas. Melalui fasilitas $E$ mail, google drive, E-book, E-library dan sosial media lainnya, informasi dan ilmu pengetahuan dapat tersampaikan tanpa melalui proses tatap muka dalam kelas konvensional.

Pada era globalisasi dengan kemajuan bidang TIK yang pesat, guru harus mampu berinovasi secara positif untuk peningkatan mutu pembelajaran. Sistem pembelajaran harus dikembangkan dari metode konvensional dimana pembelajaran klasikal adalah kegiatan utamanya menjadi pembelajaran yang lebih variatif. Untuk mendukung perubahan ini sekolah harus dilengkapi dengan sarana prasarana TIK yang memadai. Hal ini berimplikasi terhadap pergeseran peran guru di dalam kelas dari seorang pengajar menjadi seorang desainer pembelajaran, motivator, teman diskusi dan evaluator proses belajar mengajar.

Optimalisasi penggunaan TIK dalam kegiatan pembelajaran memberikan kontribusi positif setidaknya dalam hal: peningkatan kualitas belajar/ mengajar, peningkatan akses informasi, produktifitas dan efisiensi, peningkatan sikap belajar yang positif, pengembangan kompetensi profesional, dan peningkatan citra institusi sekolah. Dengan mengintegrasikan TIK dalam kurikulum pembelajaran diharapkan sekolah mengalami perubahan mendasar sesuai dengan tuntutan global dengan memperhatikan kebutuhan daerah setempat.

Secara realita penerapan TIK dalam bidang pendidikan masih mengalami banyak kendala baik fisik maupun non fisik. Secara fisik, hambatan terbesar yang ditemui saat ini adalah belum meratanya infrastuktur pendukung hingga keseluruh pelosok daerah di Indonesia [4]. Tanpa tersedianya infrastruktur TIK dan jaringan internet yang memadai, maka pengembangan media pembelajaran berbasis teknologi informasi sangat sulit dilakukan. Sehingga kualitas pendidikan di daerah terisolir akan lebih rendah dibandingkan daerah lain yang memiliki akses luas terhadap internet.

Kendala lain dalam bentuk non-fisik yang dihadapi adalah rendahnya kesiapan sumber daya manusia di sekolah dalam pemanfaatan TIK pada proses pembelajaran [5], [6]. Padahal, salah satu syarat seorang guru bisa dikategorikan sebagai tenaga pengajar profesional adalah memiliki kemampuan yang cukup dalam memanfaatkan TIK [7]. Terkait dengan pendidikan, beberapa penelitian telah dilakukan dengan tema yang bervariasi dan telah dipublikasikan dalam berbagai jurmal dan konferensi [8]-[13].

Berdasarkan hasil sebuah penelitian tentang evaluasi kompetensi guru, data menunjukan bahwa masih banyak guru di Indonesia belum memiliki pengetahuan dan kemampuan yang cukup dalam bidang TIK [14]. Hal ini disebabkan oleh pola pikir dan kebiasaan yang salah, rendahnya kepercayaan diri dan perasaan takut gagal pada guru pengajar. Guru terlihat kurang antusias dan resisten terhadap perubahan dan kemajuan teknologi. Permasalahan non-teknis ini terkadang lebih rumit untuk diselesaikan dibandingkan permasalahan teknis. Oleh sebab itu, diperlukan kesadaran dari setiap individu untuk tetap mengembangkan potensi diri dengan memanfaatkan TIK secara maksimal.

Secara teoritis, sistem pembelajaran yang terintegrasi dengan TIK akan menghasilkan proses belajar mengajar yang bercirikan [15]: aktif, konstruktif, kolaboratif, antusiastik, dialogiskomunikatif, kontekstual reflektif, multisensory (audio,visual, kinestetik) dan high order thinking (problem solving, pengambilan keputusan).

Sebenarnya, upaya peningkatan kualitas pembelajaran melalui integrasi pemakaian TIK sudah lama menjadi topik menarik untuk dipelajari. Beberapa penelitian yang telah dilakukan oleh peneliti terdahulu dalam pengembangan media pembelajaran berbasis TIK dapat ditemukan pada beberapa literatur [16]-[18].

Penelitian ini bertujuan untuk melakukan evaluasi kondisi kesiapan guru SMK di kota Padang Panjang dalam penguasaan TIK pada proses pembelajaran. Solusi alternatif ikut didiskusikan untuk peningkatan kualitas pendidikan melalui pemakaian TIK. Data dalam penelitian ini diambil melalui sebuah survei lapangan.

\section{Metode}

Pada penelitian ini, evaluasi kesiap-terapan TIK pada kegiatan belajar mengajar akan dievaluasi. Evaluasi dilakukan melalui pendekatan survei dengan menyebarkan angket kepada empat belas orang responden yang mengajar di dua SMK yang berbeda di kota Padang Panjang - Sumatera Barat. Responden terdiri dari 6 orang laki-laki dan 8 orang perempuan. Responeden yang menjadi objek penelitian dalam studi ini memiliki bidang keahlian mata pelajaran yang berbeda seperti; teknik 
bangunan, teknik mesin, teknik otomotif, bahasa Arab, bahasa Indonesia, bimbingan konseling, matematik, pendidikan agama islam dan pendidikan kewarganegaraan. Seluruh guru yang menjadi responden memiliki jenjang akademik yang sama pada level Sarjana. Usia para responden bervariasi dari 21 tahun hingga 54 tahun dengan masa kerja juga bervariasi dari 1 tahun hingga 19 tahun. Masa kerja rata-rata responden sebagai tenaga pengajar tercatat sebesar 11.4 tahun.

Analisa hasil penelitian akan dibahas secara detil dalam bab pembahasan. Gap analysis antara kondisi lapangan dengan keadaan ideal yang harus dimiliki akan didiskusikan secara mendalam. Beberapa alternatif solusi akan ditawarkan untuk menyelesaikan permasalahan yang ditemui dalam rangka meningkatkan kompetensi guru dalam pemanfaatan TIK menuju kegiatan pembelajaran yang lebih berkualitas. Hasil temuan dalam penelitian ini akan dikonfrontasi dengan berbagai referensi dari beberapa peneliti terdahulu dalam bidang kajian sejenis.

\section{HASIL DAN PEMBAHASAN}

\section{A. Ketersediaan sarana TIK dan akses internet}

Untuk bisa menggunakan TIK sebagai alat bantu KBM, minimal diperlukan dua buah prasarana penting yaitu personal computer (PC) dan akses internet pribadi di rumah. Tanpa tersedianya kedua prasarana tersebut guru tidak bisa terkoneksi ke internet untuk memperoleh data-data yang dibutuhkan. Dari hasil survei yang dilakukan, $85.7 \%$ responden menyatakan bahwa mereka memiliki perangkat komputer pribadi yang bisa digunakan setiap saat (Tabel 1). Sedangkan untuk sarana akses ke internet, hanya $78.6 \%$ responden yang memiliki akses pribadi baik melalui modem maupun fasilitas hotspot dari telepon selular (lihat Tabel 1).

Terkait dengan lama kepemilikan, dari seluruh responden yang memiliki komputer pribadi, 50\% diantaranya menyatakan bahwa mereka sudah memiliki komputer sejak lebih dari lima tahun yang lalu (Tabel 1). Hanya $21.4 \%$ persen dari total responden yang baru memiliki komputer pribadi pada kurun waktu dua tahun terakhir. Data ini menunjukan bahwa komputer dan internet hampir menjadi kebutuhan penting bagi seluruh responden.

Tersedianya jaringan internet dan fasilitas komputer pribadi di rumah, memungkinkan kita mengakses informasi kapan saja. Berdasarkan hasil survei, $28.5 \%$ dari responden menyatakan bahwa mereka terkoneksi ke internet setiap hari untuk berbagai keperluan (Tabel 1). $42.8 \%$ responden lainnya terkoneksi dengan interval waktu sambungan setiap tiga hari sekali. Sisanya menyatakan bahwa mereka akan menggunakan internet sekali dalam seminggu sesuai dengan kebutuhan.

Tabel 1. Ketersediaan sarana TIK dan akses internet pribadi

\begin{tabular}{crc}
\hline Fasilitas / peralatan & & $\begin{array}{c}\text { Persentase } \\
(\%)\end{array}$ \\
\hline Personal Computer & & 85.7 \\
Lama kepemilikan & $>$ 5 tahun & 50.0 \\
& $1-2$ tahun & 21.4 \\
& $2-5$ tahun & 28.5 \\
Lama penggunaan & Setiap hari & 28.5 \\
& $1-3$ hari & 42.8 \\
& $3-6$ hari & 28.5 \\
Akses internet pribadi & & 78.6 \\
\hline
\end{tabular}

Dengan membandingkan data ketersediaan fasilitas (komputer dan jaringan) dengan waktu pemakaian internet, dapat diketahui bahwa sebagian besar responden yang memiliki akses tidak memanfaatkan internet secara maksimal. Hal ini bisa disebabkan oleh beberapa faktor antara lain: tidak adanya kebutuhan informasi, rendahnya kemauan responden untuk terkoneksi, kurangnya ketersediaan waktu karena kesibukan, dll

\section{B. Penguasaan responden terhadap TIK}

Beberapa aplikasi TIK bisa dimanfaatkan sebagai alat bantu untuk meningkatkan kualitas KBM. Aplikasi tersebut ada yang tersedia secara gratis dan ada yang membutuhkan lisensi sebelum menggunakan. Untuk tujuan pengolahan data, presentasi, penulisan dokumen dan administrasi, beberapa software bisa dipergunakan seperti Microsoft office ${ }^{T M}$, Open Office, Soft Maker, Free Office, Libre Office, WPS Office, Zoho Docs, Google Docs, $i$ Work dll. Dari beberapa alternatif software diatas, Microsoft Office adalah aplikasi yang paling populer digunakan di Indonesia. Microsoft sendiri memiliki beberapa produk unggulan seperti Word, Excel, Power Point dll.

Tingkat kemahiran responden terhadap internet dan software lainnya untuk keperluan perkantoran ditunjukan oleh Tabel 2. Dari data yang ditunjukan pada Tabel 2, aplikasi yang sering digunakan oleh responden adalah media sosial. $35.7 \%$ dari responden menyatakan mahir dalam bermain media sosial dengan berbagai alasan dan tujuan. Sesuai dengan kondisi ril yang ditemui dilapangan, media sosial saat ini sudah berubah menjadi sebuah kebutuhan dan gaya hidup masyarakat.

Berdasarkan data penelitian (Tabel 2), aplikasi yang kurang diminati adalah website / blog pribadi. Hal ini terlihat dari data yang menunjukan bahwa 
hanya $7.1 \%$ responden yang mahir dalam pengelolaan website dan blog pribadi (Tabel 2). Sedangkan untuk search engine (google, yahoo, dll) dan E-mail, kedua aplikasi ini biasa digunakan oleh responden dengan persentase sebesar $65.3 \%$ dan $78.6 \%$ dengan kategori 'bisa menggunakan'. Kedua aplikasi ini digunakan untuk mencari informasi yang dibutuhkan dan untuk keperluan korespondensi dengan berbagai pihak. Data ini menunjukan bahwa hingga saat ini komputer dan internet lebih banyak digunakan untuk beberapa keperluan antara lain berinteraksi pada media sosial, browsing menggunakan search engine dan E-mail untuk keperluan surat-menyurat.

Tabel 2. Persentase penguasaan internet dan aplikasi TIK untuk perkantoran (dalam \%)

\begin{tabular}{rccc}
\hline Kategori & $\begin{array}{c}\text { Mahir } \\
(\%)\end{array}$ & $\begin{array}{c}\text { Bisa } \\
(\%)\end{array}$ & $\begin{array}{c}\text { Tidak } \\
\text { bisa (\%) }\end{array}$ \\
\hline Aplikasi pada internet & & & \\
Browsing & 14.3 & 78.6 & 7.1 \\
E-mail & 21.4 & 64.3 & 14.3 \\
Social media & 35.7 & 50.0 & 14.3 \\
Blog /website & 7.1 & 35.7 & 57.2 \\
Word & 14.3 & 78.6 & 7.1 \\
Excel & 14.3 & 57.1 & 28.6 \\
Aplikasi perkantoran & & & \\
Power point & 7.1 & 78.6 & 14.3 \\
Access & 7.1 & 14.3 & 78.6 \\
\hline
\end{tabular}

Mahir: mahir menggunakan, Bisa:bisa

menggunakan, tidak bisa: tidak bisa menggunakan

Sementara itu, berdasarkan evaluasi tingkat penguasaan terhadap aplikasi perkantoran (Tabel 2), data menunjukan bahwa program yang lebih banyak dikuasai oleh responden adalah MS Word, MS Excel dan MS Power point. Ketiga program ini merupakan alat bantu yang paling umum digunakan dalam penulisan naskah, modul atau jobsheet, presentasi bahan ajar dan berbagai pengolahan data seperti nilai, absensi dll. $71.4 \%$ hingga $92.9 \%$ responden menyatakan bahwa setidaknya mereka bisa megoperasikan ketiga program tersebut untuk kegiatan pembelajaran. Sedangkan untuk MS Access, program ini terlihat kurang popular digunakan. Hal ini terbukti dengan $78.6 \%$ dari responden menyatakan tidak bisa menggunakan program MS Access ini.

\section{Evaluasi pelaksanaan kegiatan pembelajaran berbasis TIK}

Proses integrasi TIK kedalam KBM di beberapa SMK saat ini belum terlaksana secara maksimal. Keberhasilan KBM berbasis TIK sebenarnya disebabkan oleh banyak faktor, diantaranya:

\section{C.1. Sarana prasarana}

Untuk bisa menggunakan TIK dalam KBM, maka dibutuhkan ketersediaan sarana prasarana yang memadai. Dalam penelitian ini dilakukan pendataan mengenai tingkat ketersediaan beberapa sarana penting seperti: komputer, LCD / proyektor, TV edukasi dan internet. Dari data hasil survei menunjukan bahwa komputer, LCD/ Proyektor dan internet merupakan sarana utama yang harus disediakan. $85.7 \%$ dari responden menyatakan bahwa sekolah mereka sudah dilengkapi minimal dengan dengan beberapa komputer, $\mathrm{LCD}$ /proyektor dan internet

Tabel 3. Persentase penggunaan peralatan TIK dalam kegiatan belajar mengajar

\begin{tabular}{lc}
\hline Alat/perlengkapan & Persentase (\%) \\
\hline Komputer & 78.6 \\
LCD/Proyektor & 71.4 \\
Internet & 71.4 \\
Multimedia & 50.0 \\
E-learning & 35.7 \\
Sosial media & 35.7 \\
Televisi & 21.4 \\
\hline
\end{tabular}

Tabel 3 menunjukan tingkat penggunaan media/ peralatan TIK dalam KBM. Sejalan dengan data ketersediaan sarana di sekolah, tiga peralatan TIK utama yang dimiliki oleh sekolah (kompter, LCD /proyektor dan internet) sangat sering dipergunakan. Setidaknya $71.4 \%$ responden menyatakan bahwa mereka menggunakan ketiga peralatan ini selama mengajar di dalam kelas (Tabel 3). Untuk perlengkapan multimedia (audivisual) lainnya telah dipergunakan oleh $50 \%$ responden untuk membantu siswa dalam menambah tingkat pemahaman. Sementara itu, E-learning dan sosial media, mulai dikembangkan untuk membantu proses belajar pada beberapa tahun terkahir. $35.7 \%$ responden menyatakan sudah pernah menggunakan E-learning dan sosial media sebagai alat bantu dalam menunjang KBM (Tabel 3). Sedangkan peralatan TIK yang termasuk jarang digunakan dalam proses pembelajaran di dalam kelas adalah televisi edukasi, karena berbagai alasan seperti tidak tersedianya fasilitas, tidak praktis dalam penyelenggaraan kegiatan, dll.

\section{C.2. Motivasi dalam menggunakan TIK untuk pembelajaran}

Meskipun sebagian besar (>71.4\%) guru sudah menggunakan komputer, LCD dan internet di sekolah, namun tidak semuanya (hanya $35.7 \%$ ) yang menggunakan E-learning dan sosial media dalam kegiatan pengajaran (Tabel 3). Namun ironisnya, 
dari dari Tabel 2 menunjukan bahwa sebagian besar responden menyatakan bisa dan mahir dalam bermain sosial media. Hal ini menunjukan bahwa meskipun terbiasa menggunakan sosial media dalam kehidupan, para guru tidak memiliki inisiatif falam memanfaatkan media sosial tersebut sebagai alat bantu untuk menunjang proses pendidikan. Disamping itu, belum populernya penggunaan Elearing di sekolah juga disebabkan oleh beberapa faktor diantaranya: belum masuknya kegiatan Elearning dalam kurikulum resmi sekolah, tidak tersedianya program yang dikembangkan sendiri oleh sekolah, kurangnya pengetahuan guru dalam mengelola mata pelajaran berdasarkan E-learning, dll. Meskipun sebenarnya, ada beberapa aplikasi Elearning yang dapat digunakan secara gratis seperti Moodle, Blackboard CourseSite, Schoology, Latitude Learning, Academy of Mine, LRN, eFront, Dokeos, Sakai,Atutor, Ilias, dll [19].

\section{Pengembangan pembelajaran berbasis TIK}

Terdapat tiga komponen penting yang sangat berpengaruh dalam pengembangan model pembelajaran berbasis TIK [20]: (1) infrastruktur, (2) konten dan aplikasi penunjang serta (3) sumber daya manusia. Dalam bidang infrastruktur beberapa kebutuhan yang diperlukan antara lain: piranti keras, piranti lunak dan jaringan baik lokal maupun global [21]. Penyediaan kebutuhan infrastruktur menjadi tugas utama pemerintah yang harus dibantu oleh semua pihak termasuk swasta dan masyarakat. Sedangkan untuk konten pembelajaran, hal ini merupakan tugas guru sebagai perancang, pelaksana dan pengevaluasi dalam sebuah kegiatan pembelajaran. Rancang bangun konten KBM harus ditunjang oleh berbagai aplikasi terkait untuk memudahkan transfer informasi yang diharapkan.

Faktor lain yang tak kalah penting dalam pengembangan pembelajaran berbasis TIK adalah kualitas sumber daya manusia. Guru sebagai pelaksana kegiatan, harus memiliki wawasan luas dan kemampuan cukup dalam bidang TIK. Apalagi pada era revolusi industri 4.0 yang berbasis pada digitali, seluruh sektor kehidupan akan dipengaruhi oleh TIK. Oleh karena itu, perlu dilakukan peningkatan kompetensi guru dalam penguasaan berbagai teknologi dan aplikasi jaringan untuk menunjang kualitas pendidikan. Peningkatan kompetensi guru bisa dilakukan melalui pelatihan pengoperasian berbagai media TIK seperti yang pernah dilakukan di kota Padang Panjang yang diselenggarakan oleh tim dari Jurusan Teknik Mesin-Otomotif Universitas Negeri Padang,

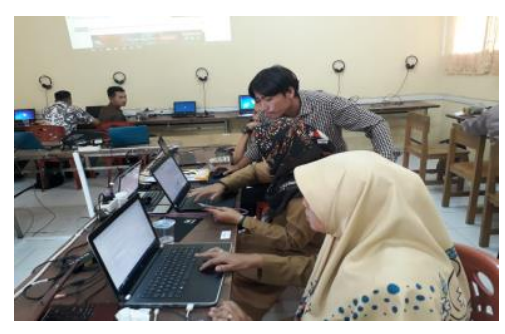

a.

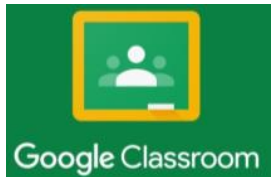

b.

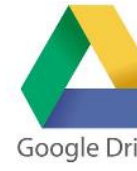

c.

\section{Google:}

d.
Gambar. 1.Pelatihan kompetensi guru dalam bidang

TIK: a. Kegiatan pelatihan, b. google-class, c. Google-drive dan d. Google-forms

Dalam pengembangan model pembelajaran berbasis TIK, terdapat beberapa prinsip dasar yang harus diperhatikan antara lain [15]: efektif dan efisien, optimal, menarik, merangsang daya kreativitas berfikir pelajar, dll. Pembelajaran berbassis TIK harus mampu mengatasi keterbatasan yang terjadi pada pembelajaran konvensional. Dengan penggunaan TIK diharapkan siswa lebih kreatif, inovatif dan adaptif terhadap perkembangan ilmu pengetahuan dan teknologi.

Saat ini model pembelajaran mulai mengarah menuju sistem full E-learning dan blended learning. Sistem E-learning memberikan kemudahan dan fleksibilitas kepada peserta didik untuk mengakses materi, mengembangan ilmu dll. Beberapa format pengajaran yang bisa digunakan pada kegiatan $E$ learning anta lain [15]: E-mail dan mailing list, web/blog, media sosial, dll.

Penggunaan TIK dalam pembelajaran memberikan beberapa keuntungan antara lain: meningkatkan kualitas interaksi (enhance interactivity), meminimalisir keterbatasan ruang dan waktu (time and place flexibility), memperluas jangkauan audiensi (global audience) dan memberikan kemudahan dalam penyimpanan dan penyempurnaan materi ajar (easy saving and updating). Dengan mengintegrasikan TIK ke dalam model pembelajaran diharapkan mampu meningkatkan kualitas pendidikan.

\section{KESIMPULAN}

Penelitian ekperimental menggunakan pendekatan survei ini memberikan gambaran terhadap kondisi ril dari implementasi penggunaan TIK dalam kegiatan pembelajaran. Dari studi kasus yang dilaksanakan di beberapa SMK di kota Padang Panjang menunjukan bahwa penggunaan TIK dalam membantu kegiatan belajar mengajar belum terlaksana secara optimal. Hal ini disebabkan oleh rendahnya kemampuan guru 
dalam penguasaan teknologi informasi dan koumnikasi. Tidak semua tenaga pengajar terbiasa menggunakan aplikasi TIK seperti e-learning, blog/web, dan beberapa software TIK lainnya seperti word, power point, excel dll. Disamping itu, kurangnya infrastruktur TIK yang tersedia di sekolah menyebabkan pengembangan model pembelajaran berbasis TIK tidak bisa dioptimalkan. Dari evaluasi kondisi lapangan, perlu dilakukan perbaikan menyeluruh termasuk meningkatkan ketersediaan infrastruktur TIK, mengembangkan konten pembelajaran yang berkualitas, menyediakan aplikasi penunjang dan meningkatkan kemampuan tenaga pengajar dalam menguasai media TIK. Hasil penelitian ini diharapkan bisa memberikan feedback yang positif dalam rangka meningkatkan kualitas pendidikan secara umum.

\section{DAfTar Pustaka}

[1] N. Y. Situmorang, 'Dampak Penggunaan Teknologi Informasi dan Komunikasi Terhadap Moral Siswa kelas XI SMK YAPIM Taruna Balige Kabupaten Toba Samosir 2017/2018', Areopagus: Jurnal Pendidikan Dan Teologi Kristen, vol. 1, no. 1, pp. 13-18, 2018.

[2] A. Praharjo, 'Perilaku Pembelian Secara Online Generasi Milenial Indonesia', MEDIA EKONOMI, vol. 19, no. 01, 2019.

[3] N. Nasution, 'Penerapan Otomasi pada Dinas Perpustakaan dan Kearsipan Kabupaten Mandailing Natal', 2019.

[4] A. Akbar and N. Noviani, 'Tantangan dan Solusi dalam Perkembangan Teknologi Pendidikan di Indonesia', in Prosiding Seminar Nasional Program Pasca Sarjana Universitas PGRI Palembang, 2019.

[5] A. D. S. Krissandi and R. Rusmawan, 'Kendala guru sekolah dasar dalam implementasi Kurikulum 2013', Cakrawala pendidikan, no. 3, 2015.

[6] H. Retnawati, 'Hambatan guru matematika sekolah menengah pertama dalam menerapkan kurikulum baru', Jurnal Cakrawala Pendidikan, vol. 34, no. 3, 2015.

[7] M. I. Ismail, 'Kinerja dan kompetensi guru dalam pembelajaran', Lentera Pendidikan: Jurnal Ilmu Tarbiyah dan Keguruan, vol. 13, no. 1, pp. 44-63, 2010.

[8] R. Lapisa, D. S. Putra, M. D. Utama, D. Setiawan, and Ambiyar, 'Evaluation of learning process using CIPP model', in 4th International Conference on Technical and
Vocational Education and Training, UNP2017, Padang, 2017, vol. 1.

[9] R. Lapisa, I. Y. Basri, A. Arif, and H. D. Saputra, 'Peningkatan Kompetensi Siswa Melalui Pelatihan Auto Cad', INVOTEK: Jurnal Inovasi Vokasional dan Teknologi, vol. 17, no. 2, pp. 119-126, 2017.

[10] I. Y. Basri, A. Arsyfadhillah, D. Irfan, and T. Thamrin, 'Rancang Bangun Media Pembelajaran Mini Trainer IC 555', INVOTEK: Jurnal Inovasi Vokasional dan Teknologi, vol. 18, no. 2, pp. 65-76, 2018.

[11] I. Basri, 'Y. 2011. Peningkatan Kompetensi Mahasiswa Di Bidang Cad/Cam Melalui Penerapan Model Pembelajaran Berbasis Remedial', Jurnal Teknologi Informasi \& Pendidikan, vol. 3, no. 1, pp. 19-30.

[12] I. Y. Basri, 'Kajian Tentang Program Pendididkan Profesi Guru Terhadap Eksistensi LPTK', proceedingfptk, vol. 437, 2015.

[13] A. Andrizal and A. Arif, 'Pengembangan Media Pembelajaran Interaktif Pada Sistem ELearning Universitas Negeri Padang, INVOTEK: Jurnal Inovasi Vokasional Dan Teknologi, vol. 17, no. 2, pp. 1-10, 2017.

[14] E. Prayitno, D. Kurniawati, and I. R. Arvianto, 'Pemanfaatan Teknologi Informasi dan Komunikasi (TIK) Untuk Meningkatkan Kualitas Pembelajaran', in Seminar Nasional Call For Paper \& Pengabdian masyarakat, 2018, vol. 1.

[15] A. Rahman, 'Desain Model dan Materi Pembelajaran Berbasis Teknologi Informasi', AL-ISHLAH: Jurnal Studi Pendidikan, vol. 16, no. 2, pp. 128-143, 2018.

[16] A. Muhson, 'Pengembangan media pembelajaran berbasis teknologi informasi', Jurnal Pendidikan Akuntansi Indonesia, vol. 8, no. 2, 2010.

[17] C. Husain, 'Pemanfaatan teknologi informasi dan komunikasi dalam pembelajaran di SMA Muhammadiyah Tarakan', Jurnal Kebijakan dan Pengembangan Pendidikan, vol. 2, no. 2, 2014.

[18] B. E. Purnama, 'Pemanfaatan Teknologi Wap Telepon Seluler Untuk Media Pembelajaran Jarak Jauh', Speed-Sentra Penelitian Engineering dan Edukasi, vol. 1, no. 3, 2008.

[19] E. F. Nugroho, Free/Open Source Learning Management System (LMS) Terbaik. 2015.

[20] I. Ishaq, 'Desain Pengembangan Pembelajaran Berbasis Teknologi Informasi Dan Komunikasi (Tik) Pada Mata Kuliah Aplikasi Komputer', Jurnal Pendidikan Fisika-Journal of Physics Education, vol. 1, no. 1, pp. 73-86, 2017. 
[21] D. Ramdani, Peta dan Tata Kelola TIK Institusi Pemerintah: Diandra Kreatif. Diandra Kreatif, 2018.

\section{Biodata Penulis}

Remon Lapisa, lahir di Padang, 18 September 1977. Menyelesaikan Sarjana Teknik Mesin di Jurusan Teknik Mesin Universita Gadjah Mada pada tahun 2001. Tahun 2011 penulis berhasil menyelesaikan program Magister of Science dalam bidang mechanical engineering di Universite de La Rochelle-France. Gelar Dr.Ing dalam bidang termal kemudian diperoleh dari universitas yang sama di Prancis pada tahun 2015. Saat ini penulis tercatat sebagai salah seorang staf pengajar di jurusan Teknik Mesin dan Teknik Otomotif Universitas Negeri Padang. Bidang penelitian yang banyak dikembangkan oleh penulis adalah konversi energi, kajian termal bangunan, thermal comfort dan efisiensi energi.

Irma Yulia Basri, dilahirkan di Solok, 07 Juli 1977. Menyelesaikan S1 pada jurusan Pendidikan Teknik Elektronika Universitas Negeri Padang tahun 2000 dan pendidikan Pascasarjana (S2) Magister Teknik bidang Teknik Elektro pada tahun 2010 di Universitas Gadjah Mada. Sejak tahun 2005 yang bersangkutan menjadi staf pengajar tetap di jurusan Teknik Otomotif Fakultas Teknik Universitas Negeri Padang.

Milana, dilahirkan di Padang Lua-Agam, 11 Mai 1982. Sarjana Teknik Industri diperoleh dari Universitas Andalas Padang pada tahun 2004, Master of Science diperoleh dari University of Bradford -United Kingdom (UK) pada tahun 2011. Pada tahun 2019 penulis memperoleh gelar Ph.D dari universitas di UK pada bidang industrial engineering. Penulis merupakan staf pengajar tetap di Jurusan Teknik otomotif Universitas Negeri padang sejak tahun 1985 hingga saat ini

Ahmad Arif, merupakan seorang staf pengajar tetap di Jurusan Teknik Otomotif UNP sejak tahun 2015. Penulis memperoleh gelar Sarjana Pendidikan bidang Teknik otomotif dari UNP pada tahun 2009 dan menyelesaikan Magister Teknik Mesin dari Institut Teknologi Sepuluh Nopember Surabaya pada tahun 2015. 